\title{
Evaluation of Nutrient Requirements of Sweet Lupine in Bread Wheat-Sweet Lupine under Additive Design Intercropping System in Northwest Ethiopia
}

\author{
Birhanu Bayeh (D), 1,2 Getachew Alemayehu (D), Tilahun Tadesse (iD, ${ }^{3}$ \\ and Melkamu Alemayehu ${ }^{1}$ \\ ${ }^{1}$ College of Agriculture and Environmental Sciences, Bahir Dar University, P.O. Box 5501, Bahir Dar, Ethiopia \\ ${ }^{2}$ College of Agriculture and Environmental Sciences, Debre Tabor University, P.O. Box 272, Debre Tabor, Ethiopia \\ ${ }^{3}$ Ethiopian Institute of Agricultural Research, Fogera Rice Research and Training Center, P.O. Box 1937, Woreta, Ethiopia
}

Correspondence should be addressed to Birhanu Bayeh; birhanub6@gmail.com

Received 4 October 2021; Accepted 28 December 2021; Published 18 January 2022

Academic Editor: Othmane Merah

Copyright ( 92022 Birhanu Bayeh et al. This is an open access article distributed under the Creative Commons Attribution License, which permits unrestricted use, distribution, and reproduction in any medium, provided the original work is properly cited.

\begin{abstract}
The application of optimal fertilizer rates for component crops improves productivity, land use efficiency, and profitability in an intercropping system. Two field experiments during the 2019 and 2020 cropping seasons were conducted in Adet and Debre Tabor districts with the objective of evaluating the nutrient requirements of sweet lupine in bread wheat-sweet lupine under additive design intercropping systems. Sweet lupine grown in bread wheat-sweet lupine intercropping was fertilized with seven fertilizer levels $(0 \%, 25 \%, 50 \%, 75 \%, 100 \%, 125 \%$, and $150 \%$ of the blanket-recommended NP fertilizer rate of sole lupine) and laid out in a randomized complete block design with three replications. The findings revealed that the highest grain yield of sweet lupine in wheat-sweet lupine intercropping system at Adet was achieved at $125 \% \mathrm{NP}\left(0.51 \mathrm{t} \cdot \mathrm{ha}^{-1}\right)$ and $150 \% \mathrm{NP}\left(0.52 \mathrm{t} \cdot \mathrm{ha}{ }^{-1}\right)$, followed by $100 \% \mathrm{NP}\left(0.43 \mathrm{t} \cdot \mathrm{ha}^{-1}\right)$ and $50 \% \mathrm{NP}\left(0.35 \mathrm{t} \cdot \mathrm{ha}^{-1}\right)$ fertilizer levels of sweet lupine. Similarly, the highest grain yield of sweet lupine in Debre Tabor was recorded by the application of $125 \%$ NP $\left(2.07 \mathrm{tha}^{-1}\right)$ fertilizer level of sweet lupine followed by $150 \% \mathrm{NP}\left(1.89 \mathrm{t} \cdot \mathrm{ha}^{-1}\right), 100 \% \mathrm{NP}\left(1.71 \mathrm{t} \cdot \mathrm{ha}^{-1}\right)$, and $50 \% \mathrm{NP}\left(1.70 \mathrm{t} \cdot \mathrm{ha}^{-1}\right)$ fertilizer levels. For every invested Ethiopian Birr in the treatments of $50 \%$ and $125 \%$ NP fertilizer levels of sweet lupine averaged additional profits of ETB 7.667 and ETB 4.537, respectively, can be obtained from sweet lupine that grew under bread wheat-sweet lupine intercropping system. Based on the averaged MRR across the different cost price ratio, application of 50\% NP fertilizer level of sweet lupine can be recommended for profitable production of sweet lupine in bread wheat-sweet lupine under additive design intercropping system in Adet and Debre Tabor and areas with similar agroecology as it recorded the highest net return with acceptable marginal rate of return.
\end{abstract}

\section{Introduction}

Ethiopia's population is growing at an alarming rate, while the food supply is increasing at a much slower rate $[1,2]$. In this regard, FAO [3] reported that farmland in the country becomes fragmented into small parcels that are less than one hectare per household at most and soil fertility of cropland has declined rapidly due to exploitative cultivation of cropland [4]. Quick corrective measures that help to sustainably increase agricultural productivity per unit of farmland are crucial. In this regard, diversification of crops through intercropping promotes land productivity and ensures the production of a given crop's sustainability. According to Panda [5], intercropping is the cultivation of two or more crop species in the same area, sharing resources for all or part of the growing season. The importance of intercropping increases as farm size decreases [6]. Intercropping supports sustainable and productive agriculture by addressing some of the major constraints associated with modern farming (monoculture) [7], such as yield stability [8], insect pests, and pathogen accumulation [9]. Moreover, intercropping provides insurance against crop failure and market fluctuations [10], soil degradation, and environmental deterioration [11], as well as lowering external inputs [12]. 
Cereal-legume intercropping is widely used in Ethiopia to ensure family food supply and income [13]. The benefits of cereal-legume intercropping systems in terms of yield may arise from complemented use of growth resources in either space or time $[14,15]$. Among cereal-legume intercropping systems, additive design intercropping is the most popular traditional practice used by low-input farmers in northwest Ethiopia [16].

Figuring out the useful or competitive effects of intercropping on soil resources, particularly nutrient supplements of the component crops is a significant and unexplored research topic. Ghosh et al. [17] found that component crops in an intercropping system compete for soil resources more intensely than for light. For many years, blanket fertilizer recommendations for the component crop in crop mixes have been used [18, 19]. Many researchers believe that fertilizer recommendations are usually based on the fertilizer requirements of the crop chosen for intercropping, although no research evidence supports this. Furthermore, Ghosh et al. [20] demonstrated that fertilizer recommendations based on the aforementioned reasons may not meet the nutrient requirement of component crops in the intercropping system, because fertilizer requirements of the component crops can be different [21].

Most fertilizer research papers, according to Maman et al. [22], mostly concentrated on establishing the optimum fertilizer rates for sole crops. Moreover, fertilizer rates advised for solitary crops have been applied on component crops in an intercropping system. While competition between component crops for nutrient usage is more pronounced in the intercropping system, this may not meet the component crop's nutrient demand [20]. In cereal-legume intercropping, there is some published information on nutrient management and nutrient audit [12]. The optimal fertilizer need of sweet lupine in intercropping bread wheatsweet lupine for improved productivity, land use efficiency, and profitability, which is different, has not yet been thoroughly researched. Thus, the objective of the present study was to assess the effects of applying NP fertilizer in sweet lupine on productivity, land use efficiency, and profitability in bread wheat-sweet lupine under an additive design intercropping system.

\section{Materials and Methods}

2.1. Experimental Sites. Field experiments were conducted in Adet and Debre Tabor districts, which are the key wheat and sweet lupine producing districts of northwest Ethiopia during the 2019 and 2020 cropping seasons. Adet district is located between $11^{\circ} 17^{\prime} \mathrm{N}$ latitude and $37^{\circ} 43^{\prime} \mathrm{E}$ longitude [23] where the experimental site is at an altitude of 2240 meters above sea level (m.a.s.l.). The other experimental site in the Debre Tabor district is located at $11^{\circ} 89^{\circ} \mathrm{N}$ and $38^{\circ} 9 \mathrm{E}$ latitude and longitude, respectively, with an elevation of about 2630 m.a.s.l. Weather data (rainfall and temperature) of the experimental years for experimental sites were collected from the northwestern Ethiopia meteorology station office in Bahir Dar, Ethiopia. The total rainfall at Adet during the 2019 and 2020 cropping seasons was 1592.1 and $1228.1 \mathrm{~mm}$,

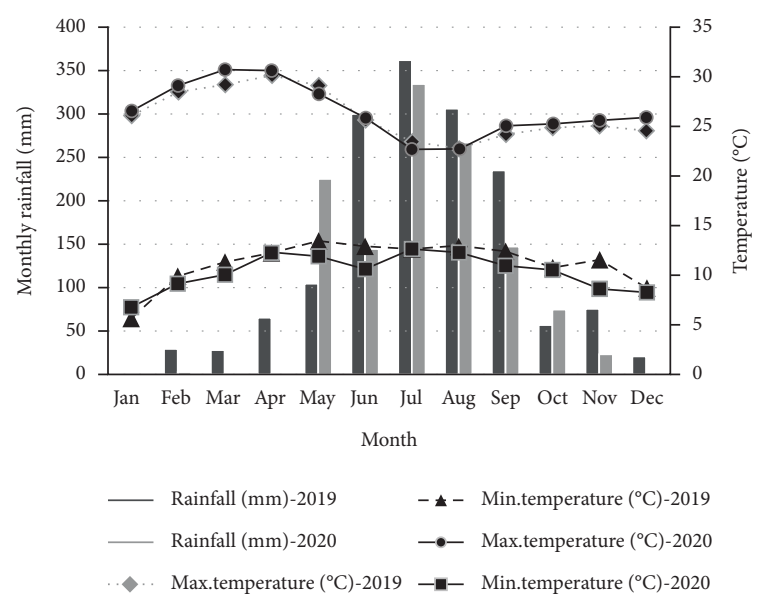

FIgURE 1: Average monthly rainfall and temperature distribution in Adet throughout the two-year experiment (2019-2020).

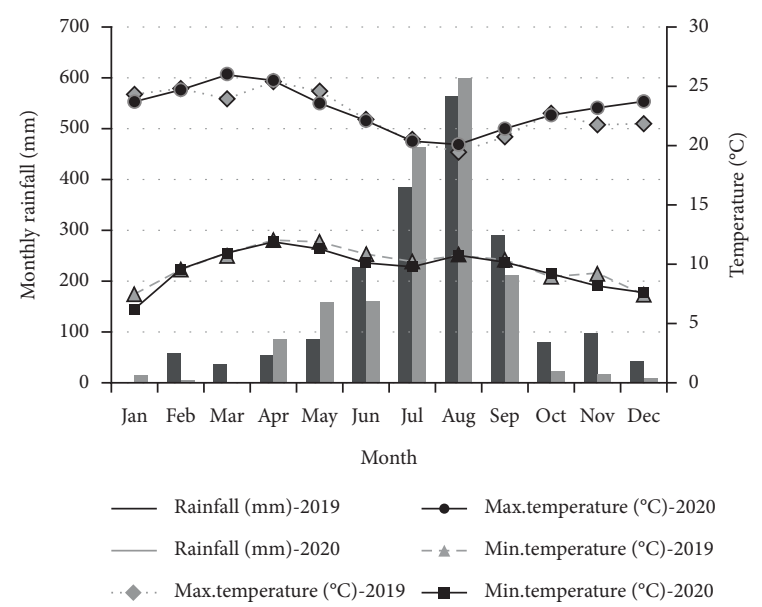

FIGURE 2: Average monthly rainfall and temperature distribution during the two experimental years (2019-2020) at Debre Tabor.

respectively (Figure 1), while at Debre Tabor it was 1926.1 and $1739 \mathrm{~mm}$, respectively (Figure 2). At Adet, the minimum and maximum temperatures were 5.4 and $30.2^{\circ} \mathrm{C}$ during 2019 and 6.8 and $30.7^{\circ} \mathrm{C}$ during 2020. At Debre Tabor, the minimum and maximum temperatures during the 2019 and 2020 cropping seasons were 7.5 and $25.3^{\circ} \mathrm{C}$ and 6.2 and $25.5^{\circ} \mathrm{C}$, respectively.

Before the start of the experiments, soil samples were collected diagonally at five spots from the depth of $0-20 \mathrm{~cm}$ and composited to evaluate the characteristics of the soil of the experimental sites. The composite soil samples were analyzed at Adet Agricultural Research Center Soil Laboratory. The soil samples were air-dried, crushed, and sieved through a $2 \mathrm{~mm}$ sieve and analyzed to determine soil texture, total nitrogen, $\mathrm{pH}$, available phosphorous, organic carbon, and cation exchange capacity. Table 1 shows the findings of the soil analysis and the methodologies used.

2.2. Treatments and Design of Experiment. Sweet lupine intercropped with bread wheat was supplied with seven different NP fertilizer rates $(0 \%, 25 \%, 50 \%, 75 \%, 100 \%$, 
TABLE 1: Soil properties of the study sites before the experiment ${ }^{\mathrm{a}}$.

\begin{tabular}{|c|c|c|c|c|c|}
\hline \multirow{2}{*}{ Soil properties } & \multicolumn{2}{|r|}{ Adet } & \multicolumn{2}{|c|}{ Debre Tabor } & \multirow[t]{2}{*}{ Method of soil analysis } \\
\hline & Value & Rating & Value & Rating & \\
\hline $\mathrm{pH}\left(\mathrm{H}_{2} \mathrm{O}\right) 1: 2.5$ & 5.08 & Moderately acidic ${ }^{\mathrm{b}}$ & 6.24 & Slightly acidic ${ }^{\mathrm{b}}$ & $\mathrm{pH}$ meter $\left(\mathrm{H}_{2} \mathrm{O} 1: 2.5\right)$ \\
\hline $\operatorname{CEC}\left(\mathrm{cmol}(+) \mathrm{kg}^{-1}\right)$ & 38.28 & $\operatorname{High}^{\mathrm{c}}$ & 42.73 & Very high $^{\mathrm{c}}$ & Ammonium acetate method [24] \\
\hline OC $(\%)$ & 1.21 & Very low ${ }^{c}$ & 1.48 & Very low ${ }^{c}$ & Walkley and Black method [25] \\
\hline $\mathrm{TN}(\%)$ & 0.17 & Low $^{c}$ & 0.16 & Low $^{c}$ & Micro-Kjeldahl method [26] \\
\hline Ava. P (ppm) & 3.89 & $\operatorname{Low}^{\mathrm{c}}$ & 21.33 & Low $^{c}$ & Bray method [27] \\
\hline Soil texture & & & & & Hydrometer method [28] \\
\hline Sand $(\%)$ & 55 & - & 56 & - & \\
\hline Silt (\%) & 11 & - & 19 & - & \\
\hline Clay $(\%)$ & 36 & - & 25 & - & \\
\hline
\end{tabular}

\begin{tabular}{lllll}
\hline Soil textural class $\quad$ Sandy clay & Sandy clay ${ }^{\mathrm{c}}$ & Sandy clay loam & Sandy clay loam
\end{tabular}

OC: organic carbon; TN: total nitrogen; Ava. P: available phosphorous; CEC: cation exchange capacity. ${ }^{a}$ Data were mean of 2 years (2019 and 2020$) .{ }^{b}$ Panda [5]. ${ }^{c}$ Landon [29].

TABLE 2: Fertilizer percentages and rates applied for sweet lupine in bread wheat-lupine intercropping system.

\begin{tabular}{|c|c|c|c|c|c|}
\hline \multirow[t]{2}{*}{ Cropping system } & \multirow[t]{2}{*}{ Percentage of the recommended rate } & \multicolumn{2}{|c|}{$\begin{array}{l}\text { Recommended } \\
\text { fertilizer rate }(\mathrm{kg} / \\
\text { ha) }\end{array}$} & \multicolumn{2}{|c|}{$\begin{array}{l}\text { Fertilizer rate of the } \\
\text { respective percentage } \\
(\mathrm{kg} / \mathrm{ha})\end{array}$} \\
\hline & & $\mathrm{N}$ & $\mathrm{P}_{2} \mathrm{O}_{5}$ & $\mathrm{~N}$ & $\mathrm{P}_{2} \mathrm{O}_{5}$ \\
\hline \multirow{7}{*}{$\mathrm{BW}+\mathrm{SL}$} & 0 & 18 & 46 & 0 & 0 \\
\hline & 25 & - & - & 4.5 & 11.5 \\
\hline & 50 & - & - & 9 & 23 \\
\hline & 75 & - & - & 13.5 & 34.5 \\
\hline & 100 & - & - & 18 & 46 \\
\hline & 125 & - & - & 22.5 & 57.5 \\
\hline & 150 & - & - & 27 & 69 \\
\hline Sole sweet lupine & 100 & 18 & 46 & 18 & 46 \\
\hline Sole bread wheat & 100 & 74 & 29 & 74 & 29 \\
\hline
\end{tabular}

BW + SL: bread wheat and sweet lupine intercropping. $\mathrm{N}$ (nitrogen) and $\mathrm{P}_{2} \mathrm{O}_{5}$ (phosphorous) are applied to the component crops in the form of urea and DAP, respectively.

$125 \%$, and $150 \%$ of recommended NP fertilizer rate of sole sweet lupine). The treatments were laid out in a randomized complete block design with three replications. Sweet lupine was planted in a $2: 1$ row-planting pattern with intra- and interrow spacing of $10 \mathrm{~cm}$ and $40 \mathrm{~cm}$, respectively (Table 2). The intercropping design was additive $(2: 1)$, while solitary cultures of the two crops were being used for estimating the partial land equivalent ratio. Sole bread wheat and sole sweet lupine sowing rates were indicated to be $150 \mathrm{~kg} / \mathrm{ha}$ and $90 \mathrm{~kg} / \mathrm{ha}$, respectively. The gross and net areas of the experimental plots were $3.6 \mathrm{~m} \times 2 \mathrm{~m}\left(7.2 \mathrm{~m}^{2}\right)$ and $3 \mathrm{~m} \times 2 \mathrm{~m}$ $\left(6 \mathrm{~m}^{2}\right)$, respectively, with a distance of $0.5 \mathrm{~m}$ and $1 \mathrm{~m}$ between adjacent plots and replications.

2.3. Experimental Materials and Planting Procedures. Taye cultivar of bread wheat, which is the most adaptable bread wheat variety, and Sanabor cultivar of sweet lupine were used as test crops. Bread wheat seeds were drilled in rows at a recommended interrow spacing of $20 \mathrm{~cm}$, while sweet lupine seeds were planted every two rows of bread wheat at inter- and intrarow spacing of $40 \mathrm{~cm} \times 10 \mathrm{~cm}$, respectively, in an additive design $(2: 1)$ intercropping system. Sole bread wheat was sown in a row at the recommended interrow spacing of $20 \mathrm{~cm}$. A sole sweet lupine was also planted in a row with a $40 \mathrm{~cm}$ interrow spacing and $10 \mathrm{~cm}$ intrarow spacing. At Adet and Debre Tabor, respectively, bread wheat in Adet experimental site was fertilized with $92 \mathrm{~kg} \cdot \mathrm{ha}^{-1} \mathrm{~N}$ and $46 \mathrm{~kg} \cdot \mathrm{ha}^{-1} \mathrm{P}_{2} \mathrm{O}_{5}$ while in Debre Tabor it was supplied with $138 \mathrm{~kg} \cdot \mathrm{ha}^{-1}$ and $46 \mathrm{~kg} \cdot \mathrm{ha}^{-1} \mathrm{P}_{2} \mathrm{O}_{5}$ as recommended. At wheat planting time, all the total amount of $\mathrm{P}_{2} \mathrm{O}_{5}$ and half of the $\mathrm{N}$ fertilizers were applied at the time of wheat planting while the remaining, half nitrogen was applied at the tillering stage. For sole sweet lupine $18 \mathrm{~kg}$, $\mathrm{ha}^{-1} \mathrm{~N}$, and $46 \mathrm{~kg}, \mathrm{ha}^{-1} \mathrm{P}_{2} \mathrm{O}_{5}$, were applied as recommended. Other agronomic practices were performed uniformly for all cropping systems as recommended.

\subsection{Data Collection}

2.4.1. Yield and Yield Attributes of Sweet Lupine in Bread Wheat-Sweet Lupine Intercropping. Branches number per plant, pod number per plant, total biomass yield, and grain yield of sweet lupine in bread wheat-sweet lupine intercropping were determined from 5 randomly sampled plants grown in the net plot area at physiological maturity. The total above-ground biomass of the component crops grown in the net plot area was measured after harvesting and sun-drying at an average air temperature of $25-27^{\circ} \mathrm{C}$ until the constant 
dry weight was attained (about two weeks). Correspondingly, the yield of the component crop was determined after the total biomass per plot was dried, threshed, cleaned, and then adjusted to a $12 \%$ moisture level.

2.4.2. Assessment of Component Crop Productiveness in Intercropping. Land equivalent ratio (LER) is a measure of the efficiency of land use in intercropping to sole cropping. It is the sum of the component crop yields. LER was calculated using the formula below as indicated by Mead \& Willey [30]. Consider the following:

$$
\text { LER }=(\text { PLERBW })+(\text { PLERSL })=\sum_{I=1}^{n}\left(\frac{Y_{i}}{Y_{m}}\right),
$$

where $Y_{i}$ and $Y_{m}$ are yields of component crops in intercrop and sole cropping, respectively, and $n$ is the number of crops involved. PLERBW: partial land equivalent ratio of bread wheat; PLERSL: partial land equivalent ratio of sweet lupine.

2.5. Data Analysis. Data analysis for the intercrop experiment was conducted using the GLM (General Linear Model) procedure of SAS version 9.2 (Statistical Analysis System (SAS) Institute, 2008) for each site and year. Finally, the data were combined over years and analyzed [31]. The least significant differences (LSD) were used to separate the means. In bread wheat-lupine intercropping systems, regression analysis was used to investigate the association between factors and NP fertilizer rates of lupine.

2.6. Partial Budget Analysis. The partial budget of the intercropping system was analyzed following the procedures described by CIMMYT [32] at three scenarios of cost price ratios. Cost price ratios were calculated by dividing the labor cost in man day ${ }^{-1}$ with grain prices of sweet lupine in $\mathrm{kg}^{-1}$. The three scenarios considered were keeping sweet lupine grain price constant while labor cost in man day ${ }^{-1}$ increased from 75 to 100 and 125 Ethiopian Birr (ETB). Labor cost included costs for planting, harvesting, threshing, and cleaning of the component crops in each treatment. The average grain price of 20 ETB per kg of sweet lupine was used for the determination of cost price ratios at both locations, which was determined based on the average local market prices in the months from December to March. Gross return minus the total costs that vary gave the net return. According to Kiwia et al. [33], the acceptability of intercropping by farmers is best judged by the marginal rates of return (MRR), an approach to maximize profit. Kiwia et al. [33] also indicated as a rule of thumb that MRR less than $100 \%$ is considered low and unacceptable to farmers; a higher cut-off value (MRR greater than 1) has been recommended if the technology involves a significant change from current farmer practices.

\section{Results and Discussion}

3.1. Growth Responses of Sweet Lupine in Bread Wheat-Sweet Lupine Intercropping to NP Fertilizer Rates. Different NP fertilizer rates had a significant $(p<0.01)$ effect on the number of branches per plant, the number of pods per plant, total biomass yield, and grain yield (Table 3) in both experimental sites. At Adet experimental site, significantly the highest branches number per plant was obtained in BW-SL intercropping at $125 \%$ and $150 \%$ NP followed by $100 \%$ NP and 50\% NP fertilizer levels (Table 3). The lowest branches number per plant of sweet lupine was recorded at zero fertilization. Similarly, the highest branches number per plant at Debre Tabor experimental site was obtained at $125 \%$ NP while the lowest branches number per plant was obtained at zero fertilization. The growth response of sweet lupine in the bread wheat-sweet lupine intercropping system increases as the NP fertilizer levels increase to the optimum level. This result agrees with the findings by Apoorva et al. [34] for wheat and chickpea. The marked difference in plant growth of the component crop was mainly due to the sufficient application of fertilizer.

The highest pod number per plant of sweet lupine at Adet was recorded from plants supplied with 150\% NP and $125 \%$ NP fertilizer levels, followed by $100 \%$ NP and 50\% NP (Table 3). Similarly, at Debre Tabor, the highest maximum pod number per plant of sweet lupine was at 125\% NP and $150 \%$ NP. The lowest pod number per plant values were recorded from plants that were not supplied with fertilizers. Generally, the number of pods per plant recorded at Debre Tabor was higher than that at Adet (Table 3). Based on the results, the yield and yield attribute of sweet lupine in the intercrop increased as the number of fertilizers increased to the optimum level. This result is also consistent with Apoorva et al. [34] findings for wheat and chickpea. The significant difference in plant growth of the component crop was primarily attributable to adequate fertilizer treatment. The higher fertilizer levels could be due to adequate nutrition levels resulting in increased root growth and penetration, allowing the component crops to explore a larger volume of soil and gain better access to nutrients. Furthermore, improved growth response at these fertilizer levels could be attributed to increased availability of nutrients from the additional fertilizer and the intercropped legume's solubility action, resulting in much release of both native and applied nutrients [35]. On the other hand, growth responses of sweet lupine were lower in bread wheat-sweet lupine intercropping that received no fertilizer, most likely due to decreased yield attributes of the component crops induced by a lack of accessible $\mathrm{N}$ and $\mathrm{P}$ in the experimental field's soil solution.

3.2. Yield Responses of Sweet Lupine in Bread Wheat-Sweet Lupine Intercropping to NP Fertilizer Rates. At Adet, the maximum total biomass yield of sweet lupine was obtained by application of $125 \%$ NP $\left(1.09 \mathrm{t} \cdot \mathrm{ha}^{-1}\right)$ followed by $150 \%$ NP $\left(0.93 \mathrm{t} \cdot \mathrm{ha}^{-1}\right)$ while the lowest total biomass yield was recorded from plants grown without fertilizer. At Debre Tabor, the highest total biomass yield of sweet lupine was achieved at $150 \%\left(4.11 \mathrm{t} \cdot \mathrm{ha}^{-1}\right)$ and $125 \% \mathrm{NP}\left(4.11 \mathrm{t} \cdot \mathrm{ha}^{-1}\right)$ fertilizer levels followed by 100\% NP (3.71 t.ha $\left.{ }^{-1}\right)$, 50\% NP $\left(3.52 \mathrm{t} \cdot \mathrm{ha}^{-1}\right)$, and $75 \% \mathrm{NP}\left(3.52 \mathrm{t} \cdot \mathrm{ha}^{-1}\right)$ while the lowest total biomass yield was at zero and 25\% NP fertilizer levels 
TABLE 3: Yield and yield attributes of sweet lupine as influenced by NP fertilizer rates in Northwest Ethiopia ${ }^{\mathrm{a}}$.

\begin{tabular}{|c|c|c|c|c|c|c|c|c|}
\hline \multirow{2}{*}{$\begin{array}{l}\text { Treatment } \\
\text { NP fertilizer } \\
\text { rate }(\%)\end{array}$} & \multicolumn{3}{|c|}{ Adet } & \multicolumn{5}{|c|}{ Debre Tabor } \\
\hline & $\begin{array}{c}\text { Branches } \\
\text { number } \\
\text { plant }^{-1}\end{array}$ & $\begin{array}{c}\text { Pods } \\
\text { number } \\
\text { plant }^{-1}\end{array}$ & $\begin{array}{l}\text { Total biomass } \\
\text { yield }\left(\mathrm{t} \cdot \mathrm{ha}^{-1}\right)\end{array}$ & $\begin{array}{l}\text { Grain yield } \\
\left(\mathrm{t} \cdot \mathrm{ha}^{-1}\right)\end{array}$ & $\begin{array}{c}\text { Branches } \\
\text { number } \\
\text { plant }^{-1}\end{array}$ & $\begin{array}{c}\text { Pods } \\
\text { number } \\
\text { plant }^{-1}\end{array}$ & $\begin{array}{l}\text { Total biomass } \\
\text { yield }\left(\mathrm{t} \cdot \mathrm{ha}^{-1}\right)\end{array}$ & $\begin{array}{c}\text { Grain yield } \\
\left(\mathrm{t} \cdot \mathrm{ha}^{-1}\right)\end{array}$ \\
\hline 0.00 & $3.00^{c}$ & $8.5^{\mathrm{c}}$ & $0.62^{\mathrm{d}}$ & $0.29^{c}$ & $3.33^{\mathrm{d}}$ & $18.00^{\mathrm{c}}$ & $2.95^{c}$ & $1.36^{\mathrm{c}}$ \\
\hline 25.00 & $3.17^{\mathrm{bc}}$ & $9.5^{\mathrm{c}}$ & $0.64^{\mathrm{d}}$ & $0.34^{\mathrm{bc}}$ & $3.33^{\mathrm{d}}$ & $18.33^{\mathrm{c}}$ & $2.96^{\mathrm{c}}$ & $1.37^{\mathrm{c}}$ \\
\hline 50.00 & $3.67^{\mathrm{bc}}$ & $13.0^{\mathrm{b}}$ & $0.79^{\mathrm{bcd}}$ & $0.35^{\mathrm{bc}}$ & $4.17^{\mathrm{bcd}}$ & $22.17^{\mathrm{b}}$ & $3.52^{\mathrm{b}}$ & $1.70^{\mathrm{b}}$ \\
\hline 75.00 & $3.17^{\mathrm{bc}}$ & $9.5^{\mathrm{c}}$ & $0.66^{\mathrm{cd}}$ & $0.35^{\mathrm{bc}}$ & $3.5^{\mathrm{cd}}$ & $22.17^{\mathrm{b}}$ & $3.52^{\mathrm{b}}$ & $1.70^{\mathrm{b}}$ \\
\hline 100.00 & $3.83^{\mathrm{b}}$ & $13.67^{\mathrm{ab}}$ & $0.87^{\mathrm{bc}}$ & $0.43^{\mathrm{ab}}$ & $4.33^{\mathrm{bcd}}$ & $23.83^{\mathrm{ab}}$ & $3.71^{\mathrm{ab}}$ & $1.71^{\mathrm{b}}$ \\
\hline 125.00 & $5.17^{\mathrm{a}}$ & $15.33^{\mathrm{a}}$ & $1.09^{\mathrm{a}}$ & $0.51^{\mathrm{a}}$ & $5.33^{\mathrm{a}}$ & $26^{\mathrm{a}}$ & $4.11^{\mathrm{a}}$ & $2.07^{\mathrm{a}}$ \\
\hline 150.00 & $4.83^{\mathrm{a}}$ & $15.67^{\mathrm{a}}$ & $0.93^{\mathrm{ab}}$ & $0.52^{\mathrm{a}}$ & $5^{\mathrm{ab}}$ & $25.17^{\mathrm{ab}}$ & $4.15^{\mathrm{a}}$ & $1.89^{\mathrm{ab}}$ \\
\hline LSD & $0.68^{* * *}$ & $2.09^{* * *}$ & $0.22^{* * *}$ & $0.1^{* * *}$ & $0.93^{* * *}$ & $3.6^{* * *}$ & $0.55^{* * *}$ & $0.28^{* * *}$ \\
\hline CV (\%) & 15.1 & 14.58 & 22.85 & 19.97 & 18.99 & 13.74 & 13.14 & 14.16 \\
\hline $\mathrm{SE} \pm$ & 0.32 & 1.12 & 0.06 & 0.04 & 0.3 & 1.18 & 0.18 & 0.1 \\
\hline
\end{tabular}

${ }^{a}$ Data were combined over years (2019 and 2020). SE: standard error of the mean; ${ }^{*},{ }^{* *}$, and ${ }^{* * *}$ indicate significance at $0.05,0.01$, and 0.001 probability levels, respectively. Means in columns with the same letter are not significantly different.

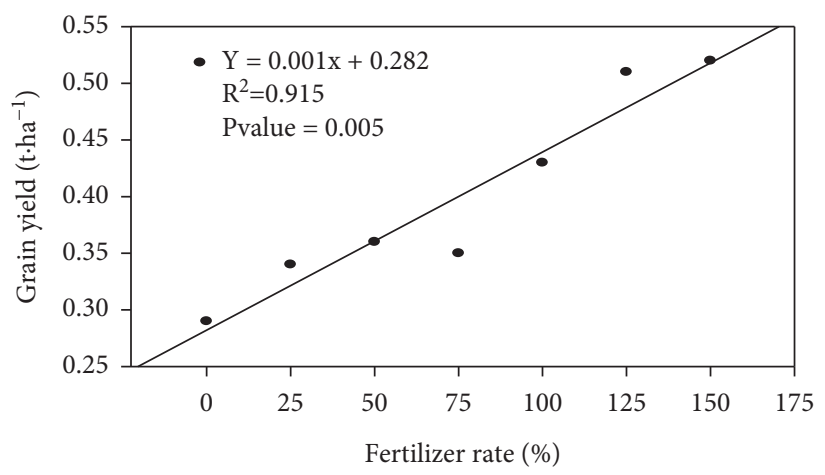

(a)

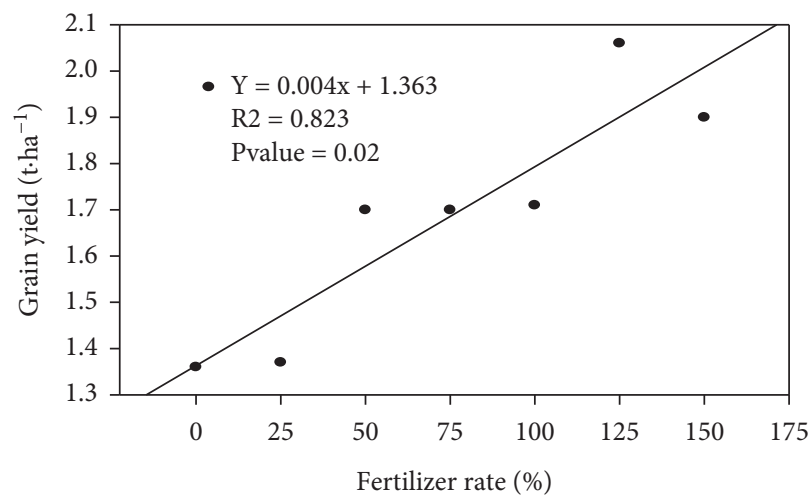

(b)

Figure 3: The relationship between grain yield of sweet lupine and fertilizer rate at (a) Adet and (b) Debre Tabor.

(Table 3). Because nutrients from mineral fertilizer were easily available, the higher NP fertilizer rates probably resulted in the highest total biomass. This may have occurred when a significant amount of fertilizer was applied to an intercrop, resulting in a decrease in interspecific competition. In line with this finding, Li et al. [36] found that increasing fertilizer application could reduce interspecific competition in an intercropping system. This result is also consistent with Azam et al. [37] findings. This result contradicts Ghosh et al. [20] findings for sorghum-soybean intercropping.

The highest grain yield of sweet lupine at Adet was recorded by application of $150 \%$ NP $\left(0.52 \mathrm{t} \cdot \mathrm{ha}^{-1}\right)$ fertilizer level, which was statistically similar with the yield recorded from $125 \% \mathrm{NP}$, followed by $100 \%\left(0.43 \mathrm{t} \cdot \mathrm{ha}^{-1}\right), 75 \%$ $\left(0.35 \mathrm{t} \cdot \mathrm{ha}^{-1}\right)$, and $50 \% \mathrm{NP}\left(0.35 \mathrm{t} \cdot \mathrm{ha}^{-1}\right)$ as indicated in Table 3. Similarly, the application of $125 \%$ NP recorded the highest grain yield $\left(2.07 \mathrm{t} \cdot \mathrm{ha}^{-1}\right)$, followed by $150 \%$ $\left(1.89 \mathrm{t}^{\mathrm{h}} \mathrm{ha}^{-1}\right)$ and $75 \%$ NP $\left(1.71 \mathrm{t} \cdot \mathrm{ha}^{-1}\right)$ at Debre Tabor. The lowest grain yields of sweet lupine on the other hand were recorded from plants, which were grown without fertilizers in both experimental sites. The relatively highest biomass and grain yields at $150 \%$ and $125 \%$ NP in both sites could be
TABLE 4: The partial land equivalent ratio of sweet lupine at Adet and Debre Tabor experimental sites.

\begin{tabular}{lcc}
\hline Fertilizer levels & $\begin{array}{c}\text { Adet } \\
\text { PLERSL }\end{array}$ & Debre Tabor \\
\hline 0\% NP of sweet lupine & 0.18 & 0.52 \\
25\% NP of sweet lupine & 0.21 & 0.52 \\
50\% NP of sweet lupine & 0.23 & 0.66 \\
75\% NP of sweet lupine & 0.22 & 0.65 \\
100\% NP of sweet lupine & 0.28 & 0.66 \\
125\% NP of sweet lupine & 0.31 & 0.79 \\
150\% NP of sweet lupine & 0.32 & 0.73 \\
\hline SSL & 1 & 1 \\
\hline SE \pm & 0.09 & 0.05
\end{tabular}

Data were combined over years (2019 and 2020). SSL: sole sweet lupine.

related to improvements in yield components for better carbohydrates partitioning from leaf to reproductive parts and efficient uptake of the applied nutrient. The linear relationship between fertilizer rate and crop yield observed in the present study also supports the idea mentioned above (Figures 3(a) and 3(b)). The grain yields of sweet lupine in Debre Tabor were relatively higher than those recorded in 
TABLE 5: Net return and marginal rate of return of sweet lupine in wheat-sweet lupine additive design intercropping system.

\begin{tabular}{|c|c|c|c|c|c|c|c|}
\hline \multirow{2}{*}{ Different NP fertilizer levels } & \multicolumn{2}{|c|}{ CPR1 } & \multicolumn{2}{|c|}{ CPR2 } & \multicolumn{3}{|c|}{ CPR3 } \\
\hline & NR $\left(\right.$ ETB ha $\left.{ }^{-1}\right)$ & $\operatorname{MRR}(\%)$ & NR $\left(\right.$ ETB ha $\left.{ }^{-1}\right)$ & MRR (\%) & NR $\left(\right.$ ETB ha $\left.{ }^{-1}\right)$ & MRR (\%) & $\mathrm{MRR}^{*}$ \\
\hline $0 \% \mathrm{NP}$ of sweet lupine & 14850 & & 14850 & & 14850 & & \\
\hline $25 \%$ NP of sweet lupine & 15040 & 54 & 15015 & 44 & 14990 & 35 & 44.3 \\
\hline $50 \% \mathrm{NP}$ of sweet lupine & 17930 & 826 & 17880 & 764 & 17830 & 710 & 766.7 \\
\hline $75 \%$ NP of sweet lupine & $17475^{\mathrm{D}}$ & & $17425^{\mathrm{D}}$ & & $17375^{\mathrm{D}}$ & & \\
\hline $100 \% \mathrm{NP}$ of sweet lupine & 17935 & 0.8 & $17860^{\mathrm{D}}$ & & $17785^{\mathrm{D}}$ & & \\
\hline $125 \%$ NP of sweet lupine & 20825 & 825 & 20725 & 276 & 20625 & 260 & 453.7 \\
\hline $150 \%$ NP of sweet lupine & $19830^{\mathrm{D}}$ & & $19730^{\mathrm{D}}$ & & $19630^{\mathrm{D}}$ & & \\
\hline
\end{tabular}

${ }^{\mathrm{D}}$ Treatments 4, 5, and 7 are dominated. Data were combined over years (2018 and 2019) and sites (Adet and Debre Tabor). CPR: cost price ratio; ETB: Ethiopian Birr; NR: net return; MRR: marginal rate of return. ${ }^{*}$ Mean marginal rate of return over the three labor cost to legume price ratios.

Adet at all treatments. However, the highest grain production at $125 \%$ NP fertilizer level was $19 \%$ and $21 \%$ higher than the respective control treatment at Adet and Debre Tabor experimental sites, respectively. In most cases, biomass and grain yield increase in line with fertilizer mount to the optimum level. The results agree with the works by Li et al. [36].

3.3. Partial Land Equivalent Ratios. A useful expression in assessing crop productivity in solitary cropping systems is mass yield (mass per unit area). Direct comparison is difficult in intercropping systems, however, because the products are different for the different plant species growing on the same area of land [38]. The PLERSL in the present study ranged from 0.18 to 0.32 in Adet and 0.52 to 0.79 in the Debre Tabor experimental locations (Table 4). When the PLER for component crops cultivated in intercropping systems is smaller than unity, according to Beyenesh et al. [39], both component crops are compatible for intercropping under varied cropping intensities. The highest PLERSL at Adet experimental site was recorded from the application of $125 \%(0.31)$ and $150 \%$ NP (0.32) fertilizer levels while the lowest (0.18) was recorded from $0 \%$ NP fertilizer level (Table 4). While in Debre Tabor, $125 \%$ NP (0.79) had the greatest PLERSL, followed by $150 \%$ NP (0.73) and 100\% NP (0.66) and 50\% NP (0.66) fertilizer levels in bread wheatsweet lupine intercropping system; the lowest PLERSL was recorded by zero fertilization. As the amount of fertilizer climbed to the optimum level, all of the intercrops in the current study had higher PLERSL. The results of the present are consistent with the results of Holland and Brummer [40] who reported better resource-use efficiency of intercrops linked to better growth conditions. Crop mixes have been shown to maximize resource usage efficiency under both marginal and better growth circumstances [41, 42].

\subsection{Profitability of Sweet Lupine in Bread Wheat-Sweet Lupine} Intercropping Systems. It is crucial to assess the impact of fertilizer rates of sweet lupine in bread wheat-sweet lupine intercropping on smallholder farm earnings in disadvantaged areas undergoing ecological degradation [43]. According to a partial budget analysis (Table 4), the highest net return (NR) and marginal rate of return (MRR) of sweet lupine were obtained from 50\% NP and 125\% NP fertilizer levels of sweet lupine in bread wheat-sweet lupine intercropping systems, respectively, across the three labor cost to legume price ratios. Under the additively designed intercropping system, investing one Ethiopian Birr (ETB) in $50 \%$ NP of sweet lupine on average (the three labor costs) recovered with additional profit of $7.667 \mathrm{ETB}$, while $125 \%$ NP of sweet lupine in bread wheat-sweet lupine 4.537 ETB of extra profit. As a result, the maximum MRR was obtained from $50 \%$ NP of sweet lupine, which could be attributable to the sweet lupine's better productivity combined with lower labor expenses. This NP fertilizer rate, in general, provides for increased land utilization and economic benefits. The MRR in the treatments $125 \% \mathrm{NP}$ and $50 \% \mathrm{NP}$ in bread wheat-sweet lupine intercropping was greater than $100 \%$ throughout all the three labor cost to price ratios, which is acceptable as indicated by CIMMYT [32]. The MRR of sweet lupine in bread wheat-sweet lupine intercropping is generally reduced as the labor cost to sweet lupine price ratio increased in the present study. As indicated in Table 5, when the labor cost to price ratio of sweet lupine increased from CPR1 to CPR2, the MRR of the treatment 50\% NP was reduced by 18.5 in bread wheat-sweet lupine intercropping systems. Based on the present study, the 50\% NP and 125\% fertilizer levels of sweet lupine in bread wheat-sweet lupine intercropping systems are economical while the use of the other rates is not economical (cost-effective) in the research areas. As can be seen, 50 percent NP is cost-effective; the amount of fertilizer used was decreased by half when compared to the suggested sole crop treatment. When compared to typical nonintercropped crop stands, nutrient utilization efficiency can be improved and fertilizer requirements of the main crops can be reduced [20,21]. This finding also revealed that using fertilizers wisely in cereallegume could produce profitable total yields per unit of land area. Intercropping corn and soybeans yielded similar outcomes [44].

\section{Conclusion}

Different NP fertilizer rates had a significant effect on yield attribute and yield of sweet lupine in bread wheat-sweet lupine at a 2:1 row ratio at Adet and Debre Tabor. At the Adet site, the highest grain yields of sweet lupine were achieved at $125 \% \mathrm{NP}\left(0.51 \mathrm{t} \cdot \mathrm{ha}^{-1}\right)$ and $150 \% \mathrm{NP}\left(0.52 \mathrm{t} \cdot \mathrm{ha}^{-1}\right)$ fertilizer levels of sweet lupine, followed by $100 \%$ NP $\left(0.43 \mathrm{t} \cdot \mathrm{ha}^{-1}\right)$ and $50 \% \mathrm{NP}\left(0.35 \mathrm{t} \cdot \mathrm{ha}^{-1}\right)$ fertilizer levels of 
sweet lupine in bread wheat-sweet lupine additive design intercropping system. Similarly, the highest grain yield at Debre Tabor was achieved by $125 \%$ NP $\left(2.07 \mathrm{t} \cdot \mathrm{ha}^{-1}\right)$ fertilizer level of sweet lupine followed by $150 \% \mathrm{NP}\left(1.89 \mathrm{t} \cdot \mathrm{ha}^{-1}\right)$, $100 \% \mathrm{NP}\left(1.71 \mathrm{t} \cdot \mathrm{ha}^{-1}\right)$, and 50\% NP $\left(1.70 \mathrm{t} \cdot \mathrm{ha}^{-1}\right)$ fertilizer levels of sweet lupine in bread wheat-sweet lupine intercropping system. The partial land equivalent ratio of sweet lupine in the bread wheat-sweet lupine intercropping system ranged from 0.18 to 0.32 and 0.52 to 0.79 at Adet and Debre Tabor, respectively. Investing one Ethiopian Birr on 50\% NP fertilizer of sweet lupine under average cost price ratio in bread wheat-lupine intercropping can help to earn an additional profit of 7.667 ETB. On the other hand, investing one Ethiopian Birr on 125\% NP fertilizer of sweet lupine under averaged cost price ratio in bread wheat-lupine intercropping can help to earn an additional profit of 4.537 ETB. As it recorded the highest MMR, application of $50 \%$ NP fertilizer level can be recommended for the production of sweet lupine in bread wheat-sweet lupine under additive design intercropping system in Adet and Debre Tabor areas and areas with similar agroecology.

\section{Data Availability}

On reasonable request, the corresponding author, Birhanu Bayeh, will provide the data that support the findings of this study.

\section{Conflicts of Interest}

The authors declare that there are no conflicts of interest.

\section{Acknowledgments}

The authors want to thank everyone who assisted with data collection at the experimental sites, data processing, writing, and publication of this study. The authors are also appreciative of the financial support provided by the Ministry of Science and Higher Education and Debre Tabor University for this experiment.

\section{References}

[1] T. Gashaw, B. Zewdu, and A. Assefa, "Effects of land fragmentation on productivity in northwestern Ethiopia," $A d$ vances in Agriculture, vol. 2017, Article ID 4509605, 9 pages, 2017.

[2] M. Wuletaw, "The link between agricultural production and population dynamics in Ethiopia: a review," Advances in Plants \& Agriculture Research, vol. 8, no. 4, pp. 348-353, 2018.

[3] Food and Agricultural Organization (FAO), The Economic Lives of Smallholder Farmers, Food and Agricultural Organization (FAO), Rome, Italy, 2015.

[4] P. Wandahwa, I. M. Tabu, M. K. Kendagor, and J. A. Rota, "Effect of intercropping and fertilizer type on growth and yield of soybean (Glycine Max L. Merrill)," Journal of Agronomy, vol. 5, no. 1, pp. 63-73, 2006.

[5] S. Panda, AgronomyNew Age International Publishers, New Delhi, India, 2010.

[6] T. Niguse and M. Reddy, "Maize/Bean intercropping effects on component yield, land use efficiency and returns at
Awasa," in Increasing Food Production through Improved Crop Management, S. Woldeyesus, T. Zerihun, and A. Nigussie, Eds., p. 51, United Printers, Addis Ababa, Ethiopia, 1996.

[7] A. S. Lithourgidis, C. A. Dordas, C. A. Damalas, and D. N. Vlachostergios, "Annual intercrops: an alternative pathway for sustainable agriculture," Australian Journal of Crop Science, vol. 5, no. 4, pp. 396-410, 2011.

[8] A. Dabbagh Mohammadi Nassab, T. Amon, and H. P. Kaul, "Competition and yield in intercrops of maize and sunflower for biogas," Industrial Crops and Products, vol. 34, no. 1, 2011.

[9] K. V. Dhima, A. S. Lithourgidis, I. B. Vasilakoglou, and C. A. Dordas, "Competition indices of common vetch and cereal intercrops in two seeding ratio," Field Crops Research, vol. 100, no. 2-3, pp. 249-256, 2007.

[10] L. Rusinamhodzi, M. Corbeels, J. Nyamangara, and K. Giller, "Maize-grain legume intercropping is an attractive option for ecological intensification that reduces the climatic risk for smallholder farmers in central Mozambique," Field Crops Research, vol. 136, no. 12-22, 2012.

[11] G. Agegnehu, A. Ghizaw, and W. Sinebo, "Yield potential and land-use efficiency of wheat and faba bean mixed intercropping," Agronomy for Sustainable Development, vol. 28, no. 2, pp. 257-263, 2008.

[12] A. Salehi, B. Mehdi, S. Fallah, H.-P. Kaul, R. W. Neugschwandtner, and W. Reinhard, "Productivity and nutrient use efficiency with integrated fertilization of buckwheat-fenugreek intercrops," Nutrient Cycling in Agroecosystems, vol. 110, no. 3, pp. 407-425, 2018.

[13] C. Fininsa and J. Yuen, "Association of bean rust and common bacterial blight epidemics with cropping systems in Hararghe highlands, Eastern Ethiopia," International Journal of Pest Management, vol. 47, no. 3, pp. 211-219, 2001.

[14] G. X. Chu, Q. R. Shen, and J. L. Cao, "Nitrogen fixation and N transfer from peanut to rice cultivated in aerobic soil in an intercropping system and its effect on soil N fertility," Plant and Soil, vol. 263, no. 1, pp. 17-27, 2004.

[15] F. Zhang and L. Li, "Using competitive and facilitative interactions in intercropping systems enhances crop productivity and nutrient-use efficiency," Structure and Functioning of Cluster Roots and Plant Responses to Phosphate Deficiency, vol. 248, no. 1-2, pp. 305-312, 2003.

[16] A. Hibstu, M. Firew, D. Yigzaw, T. Zerihun, and M. Negussie, "Challenges on production and utilization of white lupin (Lupinus albus L.) in Ethiopia: a strategic orphan crop," American Journal of Experimental Agriculture, vol. 13, no. 4, pp. 1-14, 2016.

[17] P. K. Ghosh, M. C. Manna, K. K. Bandyopadhyay et al., "Interspecific interaction and nutrient use in soybean/sorghum intercropping system," Agronomy Journal, vol. 98, no. 4, pp. 1097-1108, 2006.

[18] E. Fonduge, A. Eneji, A. Agboola, S. Yamamoto, and T. Honna, "An assessment of some fertilizer recommendations under different cropping systems in a humid tropical environment," Tropicultura, vol. 19, no. 1, pp. 21-27, 2001.

[19] V. Agoumé and Birang, "Impact of land-use systems on some physical and chemical soil properties of an oxisol in the humid forest zone of southern Cameroon," Tropicultura, vol. 27, no. 1, pp. 15-20, 2009.

[20] P. K. Ghosh, A. K. Tripathi, K. K. Bandyopadhyay, and M. C. Manna, "Assessment of nutrient competition and nutrient requirement in soybean/sorghum intercropping system," European Journal of Agronomy, vol. 31, no. 1, pp. $43-50,2009$. 
[21] M. Rostaei, S. Fallah, and A. Abbasi Sorkin, "Effect of fertilizer sources on growth, yield and yield components of fenugreek intercropped with black cumin," Journal of Crop Production, vol. 7, no. 4, pp. 197-222, 2015.

[22] N. Maman, L. Traore, M. Dicko, A. Gonda, and C. Wortmann, "Maize sole crop and intercrop response to fertilizer in Mali and Niger," Agronomy Journal, vol. 110, no. 2, pp. 728-736, 2018.

[23] Adet Agricultural Research Center (AARC), Research Achievements: A Quarter Century-Long Effort to Lift the Living Standards of Farmers, Adet Agricultural Research Center (AARC), Adet, Ethiopia, 2011.

[24] H. Chapman, "Cation-Exchange capacity," in Methods of Soil Analysis, C. A. Black, Ed., pp. 891-901, Wiley, Hoboken, NJ, USA, 1965.

[25] D. L. Heanes, "Determination of total organic-C in soils by an improved chromic acid digestion and spectrophotometric procedure," Communications in Soil Science and Plant Analysis, vol. 15, no. 10, pp. 1191-1213, 1984.

[26] J. Bremner and C. Mulvaney, "Total nitrogen," in Methods of Soil Analysis, Part 2: Chemical and Microbiological Properties, R. Miller and D. Keeny, Eds., pp. 595-624, American Society of Agronom, Madison, WI, USA, 1982.

[27] R. H. Bray and L. T. Kurtz, "Determination of total, organic, and available forms of phosphorus in soils," Soil Science, vol. 59 , no. 1 , pp. $39-46,1945$.

[28] G. Gee and J. Bauder, "Particle- size analysis," in Methods of Soil Analysis Part 1. Physical and Mineral Organic Methods agronomy, A. Klute, Ed., pp. 383-411, American Society of Agronom, Madison, WI, USA, 2nd edition, 1986.

[29] J. R. Landon, A Handbook for Soil Survey and Agricultural Land Evaluation in Tropics and Subtropics, Taylor \& Francis, Oxford, UK, 1991.

[30] R. Mead and R. W. Willey, "The concept of a "land equivalent ratio" and advantages in yields from intercropping," Experimental Agriculture, vol. 16, no. 3, pp. 217-228, 1980.

[31] K. A. Gomez and A. A. Gomez, Statistical Procedures for Agricultural Research, Wiley, Hoboken, NJ, USA, 1984.

[32] International Maize and Wheat Improvement Center (CIMMYT), From Agronomic Data to Farmer Recommendations. An Economic Training Manual, International Maize and Wheat Improvement Center (CIMMYT), Mexico, 1988.

[33] A. Kiwia, D. Kimani, R. Harawa, B. Jama, and G. Sileshi, "Sustainable intensification with cereal-legume intercropping in eastern and southern africa," Sustainability, vol. 11, no. 10, pp. 1-18, 2019.

[34] K. Apoorva, S. Prakash, N. Rajesh, and B. Nandini, "STCR approach for optimizing integrated plant nutrient supply on growth, yield, and economics of finger millet (Eleusine coracana (L.) Garten)," European Journal of Biomedical Sciences, vol. 4, pp. 19-27, 2010.

[35] W. Li, L. Li, J. Sun, F. Zhang, and P. Christie, "Effects of nitrogen and phosphorus fertilizers and intercropping on uptake of nitrogen and phosphorus by wheat, maize, and faba bean," Journal of Plant Nutrition, vol. 26, no. 3, pp. 629-642, 2003.

[36] Q. Z. Li, J. H. Sun, and X. J. Wei, “Overyielding and interspecific interactions mediated by nitrogen fertilization in strip intercropping of maize with faba bean, wheat and barley," Plant and Soil, vol. 339, no. 1-2, pp. 147-161, 2011.

[37] S. Azam, S. Mahmood, and M. Wisal, "Effect of integrated use of organic and inorganic nitrogen sources on wheat yield," Sarhad Journal of Agriculture, vol. 26, no. 4, 2010.
[38] W. C. Beets, Multiple Cropping and Tropical Farming Systems, West Views Press, Boulder, CO, USA, 1982.

[39] Z. Beyenesh, H. Mereseit, and T. Haile, "Maize and potato intercropping: a technology to increase productivity and profitability in Tigray," Open Agriculture, vol. 2, pp. 411-416, 2017.

[40] J. B. Holland and E. C. Brummer, "Cultivar effects on oatberseem clover intercrops," Agronomy Journal, vol. 91, no. 2, pp. 321-329, 1999.

[41] M. Rosegrant and Roumasset, "Effect of nitrogen on pigeon pea (Cajanus cajan) and rice (Oryza sativa) intercropping system," Indian Journal of Agricultural Sciences, vol. 60, pp. 519-522, 1990.

[42] A. Rafey and N. Prasad, "Biological potential and economic feasibility of intercropping oilseeds and pulses with safflower (Carthamus tinctorius) in drylands," Indian Journal of Agricultural Sciences, vol. 61, pp. 893-897, 1991.

[43] X. Dai, L. Pu, and F. Rao, "Assessing the effect of a crop-tree intercropping program on smallholders' incomes in rural Xinjiang, China," Sustainability, vol. 9, no. 9, 2017.

[44] A. Baghdadi, R. A. Halim, R. Othman, M. M. Yusof, and A. R. M. Atashgahi, "Productivity, relative yield and plant growth of forage corn intercropped with soybean under different crop combination ratio," Legume Research, vol. 39, no. 4, pp. 58-64, 2016. 